Joanna Szymczak

ORCID: 0000-0002-5755-5790

Uniwersytet Kazimierza Wielkiego

joannaszymczak1@gmail.com

\title{
AnAlySE jako narzędzie stymulujące rozwój refleksyjności i refleksji nauczyciela dotyczącej codzienności szkolnej
}

\section{Summary \\ AnAlySE as a tool for stimulating teacher's reflection and reflectivity with reference to everyday educational reality}

Educational situation analysis sheet (AnAlySE) was used as a tool while working with university students of early education. The work with AnAlySe was monitored in order to answer the question of its meaning in developing the ability to reflect on the everyday educational reality. The observation of students' proceedings, the interviews with them and the analysis of their work lead to the conclusion that the sheet constitutes a specific space for obtaining knowledge and developing certain skills in teacher's both individual and group work. It fosters developing the ability to learn "with" others and "from" others "in" and "from" the everyday educational reality.

Keywords: everyday educational reality, reflection and reflectivity, developing the ability to be a teacher

Słowa kluczowe: codzienność edukacyjna, refleksyjność, refleksja, analiza, budowanie bycia nauczycielem

\section{Geneza AnAlySE}

AnAlySE ${ }^{1}$, czyli arkusz analizy sytuacji edukacyjnej, to narzędzie, którego istotą jest wspieranie nauczycieli edukacji przedszkolnej oraz nauczycieli wczesnej edukacji w rozwijaniu refleksyjności i refleksji w odniesieniu do zdarzeń edukacyjnych. Powstał on w wyniku namysłu dotyczącego współpracy z nauczycielami w ramach Laboratorium Zmiany Edukacyjnej - Centrum Badań nad Rozwojem i Uczeniem², a także ze studentami pedagogiki wczesnoszkolnej i studiów doktoranckich Uniwersytetu Kazi-

\footnotetext{
1 Opisywany arkusz jest jedną z propozycji stymulowania rozwoju refleksyjności i refleksji dotyczącej codzienności szkolnej. Istnieją również inne, które uwrażliwiają nie tylko na możliwości, ale i ograniczenia związane z korzystaniem z nich - zob.: Mizerek 2015; Shank 2006; Clark, Rossiter 2008.

2 Laboratorium Zmiany Edukacyjnej - Centrum Badań nad Rozwojem i Uczeniem to jednostka naukowo-badawcza, która funkcjonuje przy Katedrze Dydaktyki i Studiów nad Kulturą Edukacji Uniwersytetu Kazimierza Wielkiego w Bydgoszczy; jej kierownikiem jest prof. dr hab. Ewa Filipiak.
} 
mierza Wielkiego w zakresie kursów: Warsztat refleksyjnego nauczyciela oraz Warsztat refleksyjnego nauczyciela akademickiego. Korzystanie przez nauczycieli, studentów i doktorantów z modelu rozwijania refleksyjności (zob.: Szymczak 2017a; Szymczak 2015a; Szymczak 2015b), stawiane przez nich pytania, doświadczane trudności, a także werbalizowane wątpliwości zmotywowały mnie do zbudowania wspomnianego arkusza. Konstrukt ten nie ma charakteru zamkniętego. Zawarte w nim pytania nie wyczerpują bowiem wszystkich aspektów, które mogą być istotne dla korzystającej z niego osoby. Kreuje on jedynie wizualną przestrzeń kulturowa dla refleksji nauczycieli dotyczącej pracy z uczniami, czyli ramę myślowa dla analizowania doświadczanej przez nich, zanurzonej w danej kulturze codzienności szkolnej. Jest materialnym wyrazem skonstruowanego modelu czy też jego swoistym uzupełnieniem. Razem z nim tworzy on otwarta catość dla rozwijania refleksyjności i namysłu nauczyciela w odniesieniu do codzienności dydaktyczno-wychowawczej.

\section{Podstawy teoretyczne}

Podstawę teoretyczną w procesie budowania AnAlySE stanowiły, takie teorie jak: konstruktywizm w ujęciu Herberta Bernera (2006), Nelsona Goodmana (1997) i Kennetha J. Gergena (2009) oraz konstruktywistyczny model poznania i nie-klasyczna socjologia wiedzy w ujęciu Andrzeja Zybertowicza (1995); interakcjonizm symboliczny w podejściu Herberta Blumera (2007) i Ervinga Goffmana (2008, 2012); fenomenologia w ujęciu Edmunda Husserla (1990), Petera L. Bergera i Thomasa Luckmanna (2010), i Alferda Schütza (2008) (zob.: Hejnicka-Bezwińska 2008: 42); autoetnografia analityczna (Anderson 2014). Nie bez znaczenia były również następujące koncepcje teoretyczne: (1) poznawcza koncepcja człowieka Józefa Kozieleckiego (1995), (2) myślenie refleksyjne w ujęciu Johna Deweya (1988), (3) refleksyjność w perspektywie teorii strukturacji Anthonego Giddensa (2003), (4) refleksyjność i bezrefleksyjność w ujęciu Ellen J. Langer (1993; Maciuszek 2013), (5) socjokulturowe podejście Jerome'a Brunera (2006), (6) koncepcja rozwojowego podejścia do edukacji Lwa S. Wygotskiego w interpretacji Ewy Filipiak $(2012,2011,2008,2002)$. Przywołane powyżej teorie stworzyły przestrzeń kulturowa dla poszukiwania odpowiedzi na pytania o to, czym jest wiedza; kim jest i jaką rolę odgrywa jednostka; kim jest badacz codzienności edukacyjnej i co znaczy budować bycie nim; kim jest nauczyciel i jaką funkcję pełni w kreowaniu środowiska uczenia się; co cechuje wrażliwe nauczanie; jak można rozumieć refleksyjność i refleksję; kim jest refleksyjny praktyk. Ponadto pomocne były zrekonstruowane w ramach projektu badawczego: typologia refleksji nauczycieli wczesnej edukacji dotyczącej pracy z uczniami, modele refleksji nauczycieli dotyczącej pracy z dziećmi, a także strategia mówienie dla myślenia (zob. szerzej: Szymczak 2017a; Szymczak 2017b; Szymczak 2017c). Uwrażliwiły mnie one bowiem na specyfikę namysłu nauczycieli dotyczącego pracy z uczniami. 


\section{Przyjęty paradygmat}

Opisywane narzędzie do analizy codzienności szkolnej usytuowałam w paradygmacie konstruktywistyczno-interpretatywnym, który jest, obok paradygmatów: pozytywistycznego, postpozytywistycznego, krytycznego (marksistowskiego, emancypacyjnego) i feministyczno-postrukturalnego, jednym z czterech podstawowych interpretatywnych paradygmatów nadających strukturę badaniu jakościowemu. Paradygmat ten charakteryzują takie właściwości, jak: relatywistyczna ontologia (zakładająca wielość rzeczywistości), subiektywistyczna ontologia (przyjmująca, że uczestnicy sytuacji edukacyjnej współtworzą jej rozumienia) i naturalistyczny zespół procedur metodologicznych (akcentujący zasadność prowadzenia badań w środowisku naturalnym dla osoby badanej). Poza tym uprawnia on do zastępowania typowych pozytywistycznych kryteriów wewnętrznej i zewnętrznej trafności, rzetelności oraz obiektywności, takimi pojęciami jak: „(...) wiarygodność, możliwość przenoszenia, niezawodność i potwierdzalność (...)" (Denzin, Lincoln 2009: 51-52; por. Szymczak 2017a: 104). Praca $\mathrm{z}$ arkuszem wymaga od nauczyciela odgrywania jednocześnie dwóch ról, tj. badacza codzienności edukacyjnej, a także obiektu badań. Tworzy mu ona bowiem przestrzeń kulturowa dla wnikliwego analizowania siebie jako przedstawiciela określonej grupy zawodowej i człowieka. Uwzględnia także różnorodność punktów widzenia, przekonan, subiektywnych filozofii edukacyjnych (zob. Lemańska-Lewandowska 2013: 19-26) i motywuje jednostkę do swoistego konfrontowania ich zarówno ze sobą, jak i z podejściem naukowym.

\section{Adresat}

AnAlySE jest adresowane do (przyszłych) nauczycieli edukacji przedszkolnej i wczesnej edukacji. Wynika to z faktu, że, po pierwsze mam przyjemność pracować głównie z nauczycielami edukacji przedszkolnej i wczesnej edukacji oraz ze studentami pedagogiki wczesnoszkolnej, a po drugie, w zrealizowanym projekcie badawczym (zob. Szymczak 2017a) uczestniczyli nauczyciele wczesnej edukacji. Brak danych empirycznych, a także niewielkie doświadczenie w pracy ze studentami innych kierunków studiów nie uprawniają mnie do rekomendowania tego narzędzia do pracy z nauczycielami pozostałych etapów kształcenia. Mogę jedynie zachęcić ich do skorzystania z arkusza, monitorowania pracy z nim, a także modyfikowania go adekwatnie do własnych potrzeb. Do tego motywuje mnie nadawanie mu wymiaru praktycznego we współpracy z doktorantami.

\section{Budowa}

Arkusz analizy sytuacji edukacyjnej zbudowany jest z trzech części. Przedstawiają się one następująco: pierwsza z nich obejmuje opis sytuacji edukacyjnej, druga jest jej analizą, a trzecia to propozycja zmiany (zmian)/proponowane rozwiązania. Część druga narzędzia składa się z trzech etapów, tj.: etap 1 - interpretacja przy korzystaniu z wiedzy uprzedniej, stadium 2 - problematyzacja/konceptualizacja, poziom 3 - interpretacja przy korzystaniu ze źródeł zewnętrznych. 
Każdą część i każdy etap budują pewne pytania, na które odpowiada nauczyciel. W części pierwszej dotyczą one tego, kto uczestniczył w określonym zdarzeniu; co zaistniało; jak przebiegała sytuacja; gdzie i kiedy miała ona miejsce; o czym myślała i co czuła osoba pracująca z narzędziem. W etapie 1 części drugiej pojawiają się pytania o motywy zachowania nauczyciela i dziecka/dzieci oraz wyboru analizowanej sytuacji edukacyjnej, a także o prawdopodobne myśli i uczucia uczestników tego zdarzenia. Etap 2 części drugiej wymaga odpowiedzi na pytanie o identyfikowane problemy/zagadnienia, w odniesieniu do których można poszukiwać literatury naukowej i dyskutować o nich z innymi. Stadium 3 części drugiej zawiera zapytania o to, do jakich wiadomości (związanych z nazwanymi problemami) dotarł nauczyciel, dzięki studiowaniu tekstów dotyczących teorii, koncepcji, modeli teoretycznych oraz rozmowom z nauczycielami i (lub) ekspertami; jak - przy korzystaniu z wiedzy, do której doszedł - interpretuje on analizowaną sytuację; czego dowiedział się o sobie, własnych przekonaniach związanych z pracą z dziećmi i projektowaniem warunków uczenia się. Pytania w części trzeciej dotyczą z kolei modyfikacji, jakie nauczyciel zamierza wprowadzić w zakresie własnej działalności, a także zmian, których dokonał w odniesieniu do własnego podejścia do pracy z uczniami. Zaproponowane w arkuszu zapytania tworzą nauczycielowi przestrzeń kulturową dla namysłu najpierw nad daną sytuacją edukacyjną, a następnie nad zidentyfikowanymi problemami/zagadnieniami.

W stadiach: 1 i 2 części drugiej nauczyciel interpretuje, nadaje znaczenia i wyjaśnia sytuację, a także zidentyfikowane problemy/zagadnienia, korzystając $\mathrm{z}$ wiedzy uprzedniej. W etapie 3 części drugiej narzędzia interpretuje on, wyjaśnia, nadaje znaczenia wyodrębnionym problemom/zagadnieniom, korzystając z literatury naukowej i/lub punktu widzenia innych osób, np. nauczycieli czy ekspertów w danej dziedzinie. Poszczególne części AnAlySE korespondują z określonymi stadiami modelu rozwijania refleksyjności nauczycieli w odniesieniu do sytuacji edukacyjnych. Część pierwsza, a także poziom 1 części drugiej narzędzia odnoszą się do etapów: I, II i III modelu. Etap 2 części drugiej arkusza dotyczy stadium IV modelu rozwijania refleksyjności. Etap 3 części drugiej arkusza współgra $\mathrm{z}$ jego poziomem $\mathrm{V}$, natomiast część trzecia narzędzia jest adekwatna do etapu VI modelu. Korespondencję między arkuszem i modelem przedstawia tabela 1.

Tabela 1. Korespondencja między AnAlySE oraz modelem rozwijania refleksyjności nauczycieli w odniesieniu do sytuacji edukacyjnych

\begin{tabular}{|c|c|}
\hline $\begin{array}{l}\text { Arkusz analizy sytuacji edukacyjnej } \\
\text { dla nauczyciela edukacji przedszkolnej } \\
\text { i nauczyciela wczesnej edukacji }\end{array}$ & $\begin{array}{l}\text { Model rozwijania refleksyjności nauczycieli } \\
\text { w odniesieniu do sytuacji edukacyjnych }\end{array}$ \\
\hline Część pierwsza & $\begin{array}{c}\text { Etap I } \\
\text { Wybór sytuacji edukacyjnej }\end{array}$ \\
\hline Opis sytuacji edukacyjnej & Etap II \\
\hline Część druga - etap 1 & Opis sytuacji edukacyjnej \\
\hline $\begin{array}{l}\text { Analiza sytuacji edukacyjnej - } \\
\text { korzystanie z wiedzy uprzedniej }\end{array}$ & $\begin{array}{l}\text { Etap III } \\
\text { Analiza przy odwołaniu się } \\
\text { do zasobów wewnętrznych }\end{array}$ \\
\hline
\end{tabular}




\begin{tabular}{|c|c|c|}
\hline $\begin{array}{c}\text { Arkusz analizy sytuacji edukacyjnej } \\
\text { dla nauczyciela edukacji przedszkolnej } \\
\text { i nauczyciela wczesnej edukacji }\end{array}$ & $\begin{array}{c}\text { Model rozwijania refleksyjności nauczycieli } \\
\text { w odniesieniu do sytuacji edukacyjnych }\end{array}$ \\
\hline $\begin{array}{c}\text { Część druga - etap 2 } \\
\text { Analiza sytuacji edukacyjnej - } \\
\text { korzystanie z wiedzy uprzedniej }\end{array}$ & $\begin{array}{c}\text { Etap IV } \\
\text { Nazwanie obszarów problemowych }\end{array}$ \\
$\begin{array}{c}\text { Część druga - etap 3 } \\
\text { Analiza sytuacji edukacyjnej - } \\
\text { korzystanie z wiedzy naukowej } \\
\text { i wiedzy innych osób }\end{array}$ & $\begin{array}{c}\text { Etap V } \\
\text { Analiza przy odwołaniu się } \\
\text { do zasobów zewnętrznych }\end{array}$ \\
\hline $\begin{array}{c}\text { Częś trzecia } \\
\text { Propozycja zmiany (zmian)/ } \\
\text { proponowane rozwiązania }\end{array}$ & $\begin{array}{c}\text { Etap VI } \\
\text { Refleksyjne wprowadzanie zmian } \\
\text { we własnej działalności }\end{array}$ \\
\hline
\end{tabular}

Źródło: opracowanie własne na podstawie: Szymczak 2017a; Szymczak 2015a.

\section{Cele}

Praca nauczyciela $\mathrm{z}$ arkuszem (a także z modelem) sprzyja osiąganiu przez niego pewnych celów. Dotyczą one dwóch aspektów jego działalności, tj.: uczenie się „w” i „,z” codzienności szkolnej w danym kontekście kulturowym oraz namysł nad własnym uczeniem się „w” i ,z” codzienności szkolnej w pewnym kontekście kulturowym. W ich zakresie tworzy on dla siebie przestrzeń kulturowa dla budowania wiedzy, a także rozwijania określonych zdolności (por.: Szymczak 2015a). Należą do nich - w odniesieniu do uczenia się „w” i ,z” codzienności szkolnej w danym kontekście kulturowym:

1) zdolność obserwowania codzienności szkolnej;

2) zdolność analizowania sytuacji edukacyjnych;

3) zdolność uwzględniania różnorodnych kontekstów/punktów widzenia/perspektyw;

4) zdolność interpretowania zdarzeń, korzystając z wiedzy uprzedniej, teorii, koncepcji i modeli teoretycznych;

5) zdolność refleksyjnego wprowadzania zmian we własnej działalności pedagogicznej.

Natomiast w odniesieniu do namysłu nad uczeniem się „w” i „z” codzienności szkolnej w pewnym kontekście kulturowym:

1) dochodzenie do rozumienia idei budowania bycia refleksyjnym nauczycielem i jej znaczenia dla pracy nauczyciela;

2) dochodzenie do tego, jakie znaczenie dla pracy nauczyciela mają teorie, a także koncepcje i modele teoretyczne.

Część pierwsza oraz etapy: 1 i 2 części drugiej AnAlySE (etapy modelu od pierwszego do czwartego) dotyczą samodzielnej pracy nauczyciela. Obserwuje on bowiem siebie w codzienności szkolnej, wybiera istotną dla niego sytuację, konstruuje jej opis, analizuje ją, korzystając z własnej wiedzy i doświadczenia, a także identyfikuje problemy/zagadnienia. Etap 2 części drugiej narzędzia (etap czwarty modelu) jest swoistym przejściem czy też mostem pomagajacym mu przejść od pracy indywidualnej do pracy z teoriami, 
koncepcjami, modelami teoretycznymi, a także z innymi osobami. Najpierw bowiem nauczyciel samodzielnie identyfikuje obszary problemowe, a następnie zaprasza do tego a także do ich analizowania - naukowców, nauczycieli i/lub ekspertów. Etap 3 części drugiej arkusza (etap piąty modelu) wymaga współpracy. Jest momentem doświadczania różnorodności punktów widzenia, podejść, perspektyw. Część trzecia narzędzia (etap szósty modelu) z kolei jest samodzielnym namysłem nauczyciela nad jego działalnością przy wykorzystaniu wiedzy zbudowanej dzięki wcześniejszym etapom.

\section{Właściwości arkusza}

Cechą charakterystyczną zbudowanego arkusza jest jego subiektywny wymiar. Pracujący z nim nauczyciel ma możliwość wprowadzania w nim określonych zmian, które ujawniają się przede wszystkim w stawianiu dodatkowych, ważnych dla niego, rodzacych się w procesie analizowania sytuacji edukacyjnej, pytań. Jest zatem narzędziem, któremu każdy nauczyciel może nadawać, przynajmniej w pewnym wymiarze, charakter indywidualny. Ponadto cechują go określone właściwości, które można przedstawić w sposób następujący:

- tworzy przestrzeń kulturowa dla wspólnej z innymi refleksji nad określonym problemem dotyczącym pracy z dziećmi;

- wymaga od nauczyciela czasu i zaangażowania (jest czaso- i pracochłonny);

- sprzyja budowaniu przez nauczyciela bycia badaczem codzienności szkolnej oraz własnego warsztatu pracy z dziećmi i innymi uczestnikami sytuacji edukacyjnych;

- sprzyja dokonywaniu przez nauczyciela samooceny rozwoju zawodowego;

- sprzyja spostrzeganiu przez nauczyciela zmian(y) dotyczących (dotyczącej) przekonań, własnej filozofii edukacyjnej w ramach analizowanej sytuacji (motywuje go do poszukiwania odpowiedzi na pytania o to, o czym i jak myślał na początku pracy ze zdarzeniem, a o czym i jak myśli po procesie jego analizy), a także w ramach określonej perspektywy czasowej (zachęca go do zastanowienia się nad tym, o czym i jak myślał oraz działał w określonym momencie rozwoju zawodowego, a jak czyni to dzisiaj).

\section{AnAlySE w praktyce}

Studenci pedagogiki wczesnoszkolnej Uniwersytetu Kazimierza Wielkiego w Bydgoszczy pracowali z AnAlySE zarówno indywidualnie, jak i w zespole. Ich działalność była procesem, w czasie trwania którego poszukiwali wsparcia w literaturze naukowej, u koleżanek i kolegów z innych zespołów, a także u ekspertów - badaczy rzeczywistości edukacyjnej. W narzędziu tym rejestrowali istotne dla nich spostrzeżenia, wnioski, komentarze oraz doświadczane trudności i sposoby radzenia sobie z nimi. Ich namysł dotyczył sytuacji, w których wchodzili w rolę nauczyciela pracującego z dziećmi lub takich okoliczności, w których byli przede wszystkim obserwatorami. W odpowiedzi na pytanie o to, czy arkusz ma znaczenie dla rozwijania ich refleksyjności i refleksji dotyczącej codzienności 
szkolnej, pomogła mi prowadzona systematycznie podczas spotkań obserwacja pracy studentów, wywiady z nimi i analiza ich wytworów, czyli wypełnionych i/lub zmodyfikowanych arkuszy. Poniżej zamieściłam fragmenty ich wypowiedzi, a także zaznaczyłam część i etap arkusza, którego one dotyczyły. Ze względu na to, że są one wyłącznie wycinka$m i$ określonej całości, często stanowiącymi konsekwencję tego, do czego autorzy doszli wcześniej, i jednocześnie punkt wyjścia dla tego, do czego dążyli, opatrzyłam je własnym komentarzem. Niektórzy studenci korzystali w procesie analizy, między innymi ze strategii, które proponuje David Tripp (1996). Przytoczone wypowiedzi pisemne pozbawione są jakiejkolwiek korekty, również językowej.

Tabela 2. AnAlySE w praktyce

\begin{tabular}{|c|c|c|}
\hline $\begin{array}{c}\text { Część } \\
\text { i etap } \\
\text { arkusza }\end{array}$ & Fragment wypowiedzi pisemnej studentów & $\begin{array}{c}\text { Komentarz } \\
\text { (J.S.) }\end{array}$ \\
\hline \multicolumn{3}{|c|}{ Zespół 1} \\
\hline $\begin{array}{l}\text { Część } \\
\text { druga, } \\
\text { etap 1 }\end{array}$ & $\begin{array}{l}\text { „- Co by się wydarzyło, gdyby nauczycielka pozostawiła pole do } \\
\text { reakcji na zdarzenie praktykantce? } \\
\text { - Co by mogło się wydarzyć, gdyby nauczycielka nie zareagowała? } \\
\text { - Co by się wydarzyło, gdyby praktykantka nie zapytała Tymka co } \\
\text { mu się nie podobało? } \\
\text { - Czy reakcja Tymka byłaby taka sama, gdyby praktykantka miała } \\
\text { dodatkowe zadania dla uczniów? (...)” }\end{array}$ & $\begin{array}{l}\text { najpierw } \\
\text { postawienie } \\
\text { pytań, } \\
\text { a następnie } \\
\text { poszukiwanie na } \\
\text { nie odpowiedzi }\end{array}$ \\
\hline \multicolumn{3}{|c|}{ Zespół 2} \\
\hline $\begin{array}{l}\text { Część } \\
\text { trzecia }\end{array}$ & $\begin{array}{l}\text { „Łącząc nasze spostrzeżenia doszłyśmy do wniosku, że } \\
\text { dobrym rozwiązaniem byłaby ,żywa lekcja” matematyki. } \\
\text { Zamiast rozwiązywać „suche” zadania na tablicy, dzieci } \\
\text { mogłyby rozwiązywać zadania w grupach, dzielić się własnymi } \\
\text { spostrzeżeniami, a nauczycielka dawałaby porady, wspierała } \\
\text { i stwarzała odpowiednie warunki do uczenia się matematyki”. }\end{array}$ & $\begin{array}{l}\text { powrót do } \\
\text { analizowanej } \\
\text { sytuacji; } \\
\text { uwrażliwianie } \\
\text { siebie na } \\
\text { określone } \\
\text { aspekty } \\
\text { działalności } \\
\text { nauczyciela }\end{array}$ \\
\hline \multicolumn{3}{|c|}{$\begin{array}{ll}\text { Praca indywidualna } 1 \\
\end{array}$} \\
\hline $\begin{array}{l}\text { Część } \\
\text { druga, } \\
\text { poziomy: } \\
1 \text { i } 3\end{array}$ & $\begin{array}{l}\text { „(...) Może zadanie było za trudne dla dzieci? Może zajęcia } \\
\text { trwały za długo? Dałam za dużo materiałów? Za mało uwagi? } \\
\text { Za mało wzmocnień? W głowie rodziło mi się wiele pytań lecz } \\
\text { nie potrafiłam znaleźć jednoznacznej przyczyny i rozwiązania } \\
\text { problemu. Postanowiłam więc skonsultować zaistniałą sytuację } \\
\text { z wychowawcą grupy, a jednocześnie z nauczycielem, który } \\
\text { ma zdecydowanie większe doświadczenie w pracy z dziećmi } \\
\text { niż ja. Gdy przedstawiłam koleżance mój problem i przebieg } \\
\text { sytuacji stwierdziła: (...) Jednakże rozmowa z koleżanką nie dała } \\
\text { mi jednoznacznej odpowiedzi (...) Odnalezienie w literaturze } \\
\text { sposobów na tego typu trudne zachowania dziecka nie było proste. } \\
\text { Jednakże w książce (...)”. }\end{array}$ & $\begin{array}{l}\text { odkrywanie } \\
\text { tego, jakie } \\
\text { znaczenie } \\
\text { dla pracy } \\
\text { z dziećmi mają } \\
\text { zidentyfikowane } \\
\text { problemy; } \\
\text { korzystanie } \\
\text { z zasobów } \\
\text { zewnętrznych }\end{array}$ \\
\hline
\end{tabular}


Tabela 2. cd.

\begin{tabular}{|l|l|l|}
\hline $\begin{array}{c}\text { Część } \\
\text { i etap } \\
\text { arkusza }\end{array}$ & \multicolumn{1}{|c|}{ Fragment wypowiedzi pisemnej studentów } & \multicolumn{1}{c|}{$\begin{array}{c}\text { Komentarz } \\
\text { (J.S.) }\end{array}$} \\
\hline $\begin{array}{l}\text { Część } \\
\text { trzecia }\end{array}$ & $\begin{array}{l}\text { „Zrozumiałam (...), że zanim rozpoczęłam jakiekolwiek działanie } \\
\text { z dziećmi powinnam chociaż trochę poznać grupę, dowiedzieć się } \\
\text { od nauczyciela na co szczególnie zwrócić uwage, czy są jakieś } \\
\text { sytuacje/zachowania trudne, których należy unikać. Taka wiedza } \\
\text { z pewnością ułatwiłaby pracę zarówno dzieciom jak mi. (...)” }\end{array}$ & $\begin{array}{l}\text { powrót do } \\
\text { analizowanej } \\
\text { sytuacji; } \\
\text { uwrażliwianie } \\
\text { siebie na } \\
\text { określone } \\
\text { aspekty } \\
\text { działalności } \\
\text { nauczyciela }\end{array}$ \\
\hline
\end{tabular}

Źródło: opracowanie własne na podstawie wypowiedzi pisemnych studentów.

Przytoczone fragmenty są egzemplifikacjami tego, że przyszli nauczyciele stworzyli sobie przestrzeń kulturową dla namysłu dotyczącego określonych aspektów codzienności szkolnej oraz tego, jakie znaczenie dla ich analizowania ma korzystanie z potencjału własnego i innych.

\section{Podsumowanie}

Skonstruowany arkusz stanowi propozycję wspierania (przyszłego) nauczyciela w budowaniu bycia refleksyjnym praktykiem. Tworzy on przestrzeń kulturowa dla rozwijania przez niego refleksyjności dotyczącej codzienności szkolnej. Jest jednocześnie narzędziem, dzięki któremu nauczyciel może zastanawiać się nad określonymi aspektami sytuacji dydaktycznych i wychowawczych. Motywuje on go do uczenia się „w” i „z” nich, a także ,z” innymi i „od” innych współtworzących je osób. Ponadto sprzyja rozwijaniu zdolności pobierania z nich próbek etnograficznych i nadawania im wymiaru krytycznego. Pozwala on nauczycielowi uwrażliwić się na dane aspekty jego działalności edukacyjnej, a także doświadczyć znaczenia teorii, koncepcji i modeli teoretycznych dla jego rozwoju. Dzięki analizowaniu własnego bycia tu i teraz (działania, odczuwania, myślenia, przeżywania w danej sytuacji edukacyjnej), nauczyciel tworzy sobie szansę nieustannego kreowania siebie jako profesjonalisty, zmieniania siebie dla tam i za chwilę. To z kolei jest związane z wyznaczaniem sobie przez niego celu, którego osiąganie domaga się monitorowania, a przestrzeń kulturowa dla tego procesu tworzy opisywany arkusz. AnAlySE koresponduje zatem z założeniami wizji „,profesjonalizmu otwartego”, zwłaszcza tymi, które dotyczą uczenia się, łączącego wiedzę ze zrozumieniem i rozwijającego zdolność krytycznego myślenia, opartego na partnerstwie, dialogu oraz koleżeńskiej współpracy (zob. Dróżka 2012: 51-55). Choć, zgodnie z koncepcją Józefa Kozieleckiego (1995), każdy człowiek jest zdolny do refleksji, to jej jakość jest zróżnicowana. Z tego powodu w pracy z arkuszem istotna jest otwartość nauczyciela na różnorodność i sprzeczność. 
Niezbędna wydaje się jego świadomość bycia zawsze uwikłanym w określony kontekst kulturowy i rezygnacja z bezrefleksyjnego transferu stworzonych rozwiązań do innego kontekstu sytuacyjnego. Jak pisze Wanda Dróżka, „(...) centralną kwestią kształcenia i rozwoju zawodowego nauczycieli staje się refleksyjność. (...) Promowanie otwartej, refleksyjnej i krytycznej perspektywy zawodu stwarza szansę na to, iż kompetentny technicznie nauczyciel, dobry fachowiec, jaki dziś jest niewątpliwie potrzebny, nie będzie się ograniczał li tylko do tzw. poszukiwania aktywnych rozwiąań, lecz będzie się zastanawiał nad szerszymi wymiarami swej pracy, nad jej celami, wartościami, warunkami oraz społeczną odpowiedzialnością za podejmowane działania (Day, 2004, s. 70)" (2012: 52-53).

\section{Literatura}

Andreson L. (2014), Autoetnografia analityczna. „Przegląd Socjologii Jakościowej”, Tom X Numer 3.

Berger P.L., Luckmann T. (2010), Społeczne tworzenie rzeczywistości. Warszawa, Wydawnictwo Naukowe PWN.

Berner H. (2006), Współczesne kierunki pedagogiczne. W: B. Śliwerski (red.), Pedagogika. Podstawy nauk o wychowaniu. Tom 1. Gdańsk, Gdańskie Wydawnictwo Pedagogiczne.

Blumer H. (2007), Interakcjonizm symboliczny. Kraków, Zakład Wydawniczy NOMOS.

Bruner J. (2006), Kultura edukacji. Kraków, Towarzystwo Autorów i Wydawnictw Prac Naukowych UNIVERSITAS.

Clark C. M, Rossiter M. (2008), Narrative Learning in Adulthood. „New Directions for Adult \& Continuing Education", 119.

Denzin N.K., Lincoln Y.S. (2009), Wprowadzenie. Dziedzina i praktyka badań jakościowych. W: N.K. Denzin, Y.S. Lincoln (red.), Metody badań jakościowych. Tom 1. Warszawa, Wydawnictwo Naukowe PWN.

Dewey J. (1988), Jak myślimy? Warszawa, „Książka i Wiedza”.

Dróżka W. (2012), Dylematy jakości nauczyciela wobec zmienności kulturowo-społecznego kontekstu jego pracy. W: B.D. Gołębniak, H. Kwiatkowska (red.), Nauczyciele. Programowe (nie) przygotowanie. Wrocław, Wydawnictwo Naukowe Dolnośląskiej Szkoły Wyższej.

Filipiak E. (2012), Rozwijanie zdolności uczenia się. Z Wygostkim i Brunerem w tle. Sopot, Gdańskie Wydawnictwo Psychologiczne.

Filipiak E. (2011), Z Wygotskim i Brunerem w tle: Słownik pojęć kluczowych. Bydgoszcz, Wydawnictwo Uniwersytetu Kazimierza Wielkiego.

Filipiak E. (2008), Uczenie się w klasie szkolnej w perspektywie socjokulturowej. W: E. Filipiak (red.), Rozwijanie zdolności uczenia się. Wybrane konteksty i problemy. Bydgoszcz, Wydawnictwo Uniwersytetu Kazimierza Wielkiego.

Filipiak E. (2002), Konteksty rozwoju aktywności językowej dzieci w wieku wczesnoszkolnym. Bydgoszcz, Wydawnictwo Akademii Bydgoskiej im. Kazimierza Wielkiego.

Gergen K.J. (2009), Nasycone Ja. Dylematy tożsamości w życiu współczesnym. Warszawa, Wydawnictwo Naukowe PWN.

Giddens A. (2003), Stanowienie społeczeństwa. Poznań, Zysk i S-ka Wydawnictwo.

Goodman N. (1997), Jak tworzymy świat. Warszawa, Fundacja Aletheia.

Goffman E. (2012), Rytuat interakcyjny. Warszawa, Wydawnictwo Naukowe PWN. 
Goffman E. (2008), Człowiek w teatrze życia codziennego. Warszawa, Wydawnictwo Aletheia.

Hejnicka-Bezwińska T. (2008), Pedagogika ogólna. Warszawa, Wydawnictwa Akademickie i Profesjonalne.

Husserl E. (1990), Idea fenomenologii. Pięć wykładów. Warszawa, Państwowe Wydawnictwo Naukowe.

Kozielecki J. (1995), Koncepcje psychologiczne człowieka. Warszawa, Wydawnictwo „Żak”.

Langer E.J. (1993), Problemy uświadamiania. Konsekwencje refleksyjności i bezrefleksyjności. W: T. Maruszewski (red.), Poznanie. Afekt. Zachowanie. Warszawa, Wydawnictwo Naukowe PWN.

Lemańska-Lewandowska E. (2013), Nauczyciele a dyscyplina w klasie szkolnej. Przekonania Strategie - Kierunki zmian. Bydgoszcz, Wydawnictwo Uniwersytetu Kazimierza Wielkiego.

Maciuszek J. (2013), Automatyzmy i bezrefleksyjność w kontekście wpływu społecznego. Warszawa, Wydawnictwo Naukowe PWN.

Mizerek H. (2015), Evidence-Based Practice in Education: Premises, Dilemmas, Prospects. "Forum Oświatowe", 27(2).

Schütz A. (2008), O wielości światów. Kraków, Zakład Wydawniczy NOMOS.

Shank M.J. (2006), Teacher storytelling: A means for creating and learning within collaborative space. „Teaching and Teacher Education”, 22.

Szymczak J. (2017c), Co się dzieje w umysłach nauczycieli, kiedy myśla o pracy z uczniami. „Teraźniejszość-Człowiek-Edukacja", 3(79).

Szymczak J. (2017b), Typologia nauczycielskiej refleksji dotyczacej pracy z uczniami. „Problemy Wczesnej Edukacji”, 3(38).

Szymczak J. (2017a), Refleksja nauczycieli wczesnej edukacji dotyczaca pracy z uczniami (w perspektywie badań rekonstrukcyjnych). Studium teoretyczno-metodologiczne. Bydgoszcz, Wydawnictwo Uniwersytetu Kazimierza Wielkiego.

Szymczak J. (2015a), Model rozwijania refleksyjności u (przyszłych) nauczycieli edukacji wczesnoszkolnej-założenia, istota, motywy konstruowania i nadawania mu wymiaru praktycznego. „Problemy Wczesnej Edukacji”, 1(28).

Szymczak J. (2015b), (Wspót)bycie/(wspót)stawanie się refleksyjnym nauczycielem i uczniem. Portfolio oraz feedback jako strategie działania ku refleksyjności. W: E. Filipiak (red.), Nauczanie rozwijające we wczesnej edukacji wedlug Lwa S. Wygotskiego. Od teorii do zmiany w praktyce (s. 181-202). Bydgoszcz, Agencja Reklamowo-Wydawnicza ArtStudio.

Tripp D. (1996), Zdarzenia krytyczne w nauczaniu. Ksztaltowanie profesjonalnego osadu. Warszawa, Wydawnictwa Szkolne i Pedagogiczne.

Zybertowicz A. (1995), Przemoc i poznanie. Studium z nie-klasycznej socjologii wiedzy. Toruń, Uniwersytet Mikołaja Kopernika. 